\title{
CORPORATE GOVERNANCE, POLITICAL CONNECTIONS, AND EARNINGS MANAGEMENT
}

\author{
Ni Nyoman Iin Purnama Sari ${ }^{1)}$, Ni Wayan Rustiarini ${ }^{2 *}$, Ni Putu Shinta Dewi ${ }^{3)}$ \\ 1,2,3 Department of Accounting, Faculty of Economic and Business, Mahasaraswati Denpasar \\ University, Indonesia
}

\begin{abstract}
Earnings management is management exertion to manage the company's financial statements. This study aims to examine the effect of corporate governance and political connection on earnings management. The corporate governance variable was reviewed using four proxies: bonus compensation, institutional ownership, independent commissioners, and financial expertise of audit committee. The study was conducted on 183 manufacturing companies on the Indonesian Stock Exchange for three research periods, namely 2017-2019. This study uses multiple linear regression to test the research hypotheses. The results support that bonus compensation increase the propensity of earnings management, while institutional ownership it is confirmed that institutional ownership reduces earnings management. However, the other three variables, namely independent board of commissioners, financial expertise of audit committee, and political connections, do not affect earnings management practices. This research contributes policy for the government to focus on the implementation of good governance. Besides, the government needs to consider the impact of bonus compensation on increased earnings management.
\end{abstract}

Keywords: earning management, corporate governance, bonus compensation, political connections

\section{INTRODUCTION}

Earnings information is one of the indicators to assess management performance. Performance appraisal based on earnings information motivates management to meet the targeted profit value. Profit shows management's achievement and becomes a means to maintain management's position in the company (Mardjono \& Chen, 2020). This condition triggers management to make all efforts to meet management's expectations (Dalia et al., 2021; Yustiningarti \& Asyik, 2017). Therefore, one activity that is frequently committed is earnings management. Earnings management is management exertion to manage the company's financial statements by selecting specific accounting policies (Prasetya \& Gayatri, 2016). Management tends to do earnings management if it cannot meet the profit target set by the shareholders.

One of the earnings management cases that occurred in Indonesia was carried out by the airline company PT Garuda Indonesia Tbk. In 2017, the company claimed a company loss of US\$ 216.58 million. However, this company announced US\$ 809,846 as a net profit in 2018 . Also, there was a significant increase in profit due to the company's overstatement of revenue recording (Cnbcindonesia.com, 2019). This case raises public questions about corporate governance's role in the financial information reporting process. Moreover, Garuda Indonesia is one of the SOEs with a mandate from the people and the state. Therefore, this study explores the role of corporate governance and the political connection to earnings management.

*Corresponding author. Email address: rusti_arini@unmas.ac.id 


\section{AFEBI Economic and Finance Review (AEFR)}

\section{Volume 6, No 2 (2021)}

This study uses four variables representing corporate governance: bonus compensation, institutional ownership, independent commissioners, and financial expertise of audit committees. One of the factors that inspire management to commit earnings management is bonus contracts. Managers tend to manage net income to maximize their bonuses (Moradi et al., 2015; Scott, 2009). However, this study still leads to inconsistencies. Previous research states that bonus compensation improves earnings management (Elfira, 2014; Yustiningarti \& Asyik, 2017). However, other results stated that bonus compensation reduces earnings management (Azizi et al., 2018). Based on the corporate governance context, institutional ownership has a crucial part in monitoring financial reporting. Significant share ownership motivates them to commit adequate supervision (Sumanto et al., 2014). Thus, institutional ownership reduces the possibility of earnings management (Nazir, 2014; Sumanto et al., 2014).

Independent commissioners also implement the role of supervision. This member is free from the company's internal interests so that it is considered capable for reducing the potential of earnings management (Mardjono \& Chen, 2020; Nazir, 2014; Rahmawati et al., 2017). Another company organ that reduces earnings management frequency is the audit committee. Audit committee members with accounting or financial expertise analyze and evaluate financial statements to prevent earnings management (Dwiharyadi, 2017; Widasari \& Isgiyarta, 2017). Other factors, such as political connections, also determine the potential for earnings management (Dalia et al., 2021). Political connections encourage companies to commit earnings management, mainly when tax evasion (Antonius \& Tampubolon, 2019).

This study aims to examine the effect of corporate governance and political connection on earnings management. Theoretically, this study supports the agency theory that shareholders as the principal want to improve welfare through achieving maximum profitability. Therefore, the implementation of good corporate governance reduce the potential for earning management. This research contributes policy for the government to focus attention on the implementation of good governance. Besides, the government considers the impact of political connections to increase earnings management.

\section{LITERATURE STUDY}

\section{Agency Theory}

Jensen and Meckling (1976) definite an agency relationship as an employment contract between principal and agent. Shareholders as the principal want to improve welfare through achieving maximum profitability. Likewise, managers as agents are also motivated to maximize their interests. Thus, the existence of a difference of interest gives rise to an agency conflict. Moreover, agents seek to engage in opportunistic behavior to maximize their interests, such as earnings management.

\section{Bonus Compensation and Earnings Management}

Bonus compensation motivates managers to work to maximize company profits (Moradi et al., 2015). Compensation includes financial and non-financial benefits, as well as other benefits received by employees. The provision of compensation encourages managers to maximize performance to achieve the targeted profit value (Haque, 2017). Managers will get several bonuses if the company's profit achievement is in the range of the lower limit (boogey) and the upper limit (cap) set (Healy, 1985). However, this demand encourages managers to manipulate earnings if the profit achievement is not according to the targeted value. Previous research has proven that bonus compensation positively affects earnings management (Elfira, 2014; Yustiningarti \& Asyik, 2017). Thus, the hypothesis formulated is:

$\mathrm{H}_{1}$ : Bonus compensation has a positive effect on earnings management. 


\section{Institutional Ownership and Earnings Management}

Institutional ownership is share ownership by the institution. Jensen and Meckling (1976) asserted that institutional ownership is effective in minimizing agency conflict. Institutional investors have sufficient experience and information about the company's operational activities. Thus, this ownership can reduce information asymmetry through an effective monitoring process (Nazir, 2014). A large percentage of share ownership in a corporate governance context allows investors to influence preparing financial statements. This authority can rule out the possibility of accrual of financial information by the management (Marsha \& Ghozali, 2017). Thus, institutional ownership effectively reduces earnings management (Nazir, 2014; Sumanto et al., 2014). Thus, the hypothesis formulated is:

$\mathrm{H}_{2}$ : Institutional ownership has a negative effect on earnings management.

\section{Independent Commissioner and Earnings Management}

The board of commissioners is a corporate element that has monitoring management performance function. The board of commissioners consists of independent members who are not affiliated with the company's management. Independent commissioners are deemed capable of performing a practical supervisory function on management performance, including financial reporting (Murni et al., 2016). It is because this membership is free from various internal company interests. Furthermore, an independent monitoring process in preparing financial statements creates the presentation of quality earnings information (Nazir, 2014). Thus, an independent commissioner effectively reduces the fraud possibility (Nazir, 2014; Rahmawati et al., 2017). Thus, the hypothesis formulated is:

$\mathrm{H}_{3}$ : independent commissioners have a negative effect on earnings management.

\section{Audit Committee with Financial Expert and Earnings Management}

The audit committee is a company organ that carries out its duties as the company's internal supervisor. This role is regulated in the Financial Services Authority regulation No. 55/POJK.04/2015 about the establishment and guidelines for audit committee duties implementation. The regulation emphasizes the importance of audit committee members having an accounting or financial education background (financial or accounting expert) (Mardjono \& Chen, 2020; Zalata et al., 2018). Audit committee members with financial expertise can intensively analyze and evaluate financial statements (Dwiharyadi, 2017; Juhmani, 2017). Besides, the audit committee can monitor the company's internal control system to prevent managers' opportunistic behavior (Khosheghbal et al., 2017). The more members of the accounting or financial experts, the lower the earnings management probability (Zalata et al., 2018). Previous research has proven that financial experts of audit committee members reduce earnings management practices (Inaam \& Khamoussi, 2016; Mardjono \& Chen, 2020; Widasari \& Isgiyarta, 2017; Zalata et al., 2018). Thus, the hypothesis formulated is:

$\mathrm{H}_{4}$ : The audit committee with financial experts has a negative effect on earnings management.

\section{Political Connections and Earnings Management}

Political connection is the condition of the existence of a particular party's affiliation relationship with other parties that have political interests or links to reach an agreement that benefits both parties (Haryati et al., 2021; Sugiyarti, 2017). Political connections are a valuable opportunity for companies to establish unique relationships with government agencies or political parties with close ties to the government (Pranoto \& Widagdo, 2015). The political connections measure from the proximity of the commissioners or directors to the government or political parties (Antonius \& Tampubolon, 2019). Previous research stated that politically connected companies tend to practice tax avoidance because they feel close to tax regulators (Antonius \& Tampubolon, 2019; Kovermann \& Velte, 2019). One of the actions to carry out 


\section{AFEBI Economic and Finance Review (AEFR)}

\section{Volume 6, No 2 (2021)}

tax avoidance is through earnings management. Thus, the political connections increase the potential for earnings management (Braam et al., 2015). Thus, the hypothesis formulated is: $\mathrm{H}_{5}$ : Political connection has a positive effect on earnings management.

\section{RESEARCH METHODOLOGY}

The research population consists of manufacturing companies on the Indonesian Stock Exchange in 2017-2019. This study uses manufacturing companies because most companies listed on the Indonesian Stock Exchange are manufacturing companies. Sampling used the purposive sampling method because sampling requires specific criteria, such as earning a profit and having the variables needed in this study. Thus, 61 companies meet these criteria or 183 data observations for the three years of the study. The dependent variable is earnings management. The independent variable consists of five variables: bonus compensation, institutional ownership, independent commissioners, audit committees with financial experts, and political connections.

The earnings management variable is measured by discretionary accruals, calculating the difference between total accruals and non-discretionary accruals (modified Jones model). In the calculation of discretionary accruals, the total accruals are first measured. Furthermore, total accruals are classified into two categories, namely discretionary and non-discretionary (Sulistyanto, 2008:225), through the following stages:

a. The measurement of total accrual using the modified Jones model.

Total Accrual $(\mathrm{TAC})=$ net income - cash flow from operating.

b. Calculating the estimated accruals value using Ordinary Least Square (OLS), with the equation:

$\frac{T A_{i t}}{A_{i t-1}}=\beta_{1}\left(\frac{1}{A_{i t-1}}\right)+\beta_{2}\left(\frac{\Delta R e v_{i t}}{A_{i t-1}}\right)+\beta_{3}\left(\frac{\mathrm{PPE}_{i t}}{A_{i t-1}}\right)+\varepsilon$

Information:

$\mathrm{TA}_{\mathrm{it}}=$ total accruals of a company $\mathrm{i}$ in period $\mathrm{t}$

$\mathrm{A}_{\mathrm{it}-1}=$ total assets for sample company $\mathrm{i}$ at the end of year $\mathrm{t}-1$

$\mathrm{REV}_{\text {it }}=$ change in revenue of company $\mathrm{i}$ from year $\mathrm{t}-1$ to year $\mathrm{t}$

$\mathrm{PPE}_{\mathrm{t}}=$ fixed assets (gross property plant and equipment) company year $\mathrm{t}$

$\beta=$ regression coefficient (beta)

$\varepsilon=$ error

c. Calculating non-discretionary accruals model (NDA) is as follows:

$$
N D A_{i t}=\beta_{1}\left(\frac{1}{A_{i t-1}}\right)+\beta_{2}\left(\frac{\Delta \operatorname{Rev}_{i t}}{A_{i t-1}}-\frac{\Delta \operatorname{Rec}_{i t}}{A_{i t-1}}\right)+\beta_{3}\left(\frac{\mathrm{PPE}_{i t}}{A_{i t-1}}\right)
$$

Information:

NDAit $=$ non-discretionary accruals of a company $\mathrm{i}$ in year $\mathrm{t}$

Ait-1 = total asset change $\mathrm{i}$ at the end of year $\mathrm{t}-1$

RECit = receivables of a company $i$ in year $t$

RECit-1 = receivables of a company $i$ in year $t-1$

REVit = change in revenue of company i from year $\mathrm{t}-1$ to year $\mathrm{t}$

PPEit $=$ total fixed assets of a company $\mathrm{i}$ at the end of year $\mathrm{t}$

d. Calculating discretionary accruals:

$D A_{i t}=\frac{T A_{i t}}{A_{i t-1}}-N D A_{i t}$

Information:

$\mathrm{DA}_{\mathrm{it}}=$ discretionary accruals of a company $\mathrm{i}$ in year period $\mathrm{t}$ 
TAit $=$ total accruals of a company $\mathrm{i}$ in period $\mathrm{t}$

Ait-1 = total asset change $\mathrm{i}$ at the end of year $\mathrm{t}-1$

NDAit $=$ non-discretionary accruals of a company $\mathrm{i}$ in year $\mathrm{t} \mathrm{t}$

The bonus compensation variable is the company's reward to the manager, which is given in the form of a bonus. This variable uses a nominal scale in the form of a dummy variable, namely if it is coded 1 (one) if there is a bonus compensation given to management and code 0 (zero) for the opposite (Elfira, 2014). The institutional ownership variable is measured using the percentage of institution shares compared to the total share capital outstanding in the stock market. An independent board of commissioners variable uses a ratio scale in the form of a percentage, namely the number of independent commissioners compared to the total number of commissioners. Furthermore, an audit committee with a financial expert is measured using a percentage, namely the number of financial (accounting) experts members compared to the total number of audit committee members. Finally, the political connection variable is explained using a nominal scale in the form of a dummy variable, coded 1 if the company has political connections and code 0 otherwise. The criteria for identifying political connections refer to previous research (Rustiarini \& Sudiartana, 2021), namely:

a. One of the directors or commissioners of the company is a member of the legislature, an organization executive member, a government institution official, including the military, or a member of a political party.

b. One of the directors or commissioners is a former member of the legislature, former executive member of the organization, former official in a government institution, including former military or former political parties.

c. One of the owners/shareholders of the company above $10 \%$ is a member of a political party, official, or government official, including military and political members.

The analytical technique to examine the research hypotheses is multiple linear regression analysis using SPSS.

\section{RESULT AND DISCUSSION}

Result

Descriptive statistics describe data to provide information related to variable characteristics, such as mean, standard deviation, maximum, minimum (Ghozali, 2016:123). The descriptive statistical calculation of this variable is presented in Table 1.

Table 1. Descriptive Statistics Test Results

\begin{tabular}{llllll}
\hline Variables & $\mathbf{N}$ & Minimum & Maximum & Mean & $\begin{array}{l}\text { Std } \\
\text { Deviation }\end{array}$ \\
\hline Earning management & 183 & -.42 & .01 & -.03 & .03 \\
Bonus compensation & 183 & .00 & 1.00 & .60 & .49 \\
Institutional ownership & 183 & .20 & .85 & .65 & .25 \\
Independent commissioner & 183 & .33 & .80 & .43 & .11 \\
$\begin{array}{l}\text { Audit committee financial } \\
\text { expert }\end{array}$ & 183 & .00 & 1.00 & .62 & .23 \\
$\begin{array}{l}\text { Political connection } \\
\text { Valid N (listwise) }\end{array}$ & 183 & .00 & 1.00 & .21 & .41 \\
\hline
\end{tabular}

Source: processed data (2021)

Table 1 shows that the earnings management variable has an average value of -0.03 . The average value of the bonus compensation is 0.60 . It means that $60 \%$ of companies distribute bonus compensation to management. Meanwhile the institutional ownership variable has a mean value of 0.65 . The variable, independent commissioners, has a mean of 0.43 . Finally, the audit committee variables with financial expert and political connection have an average of 0.62 and 0.21. Furthermore, this study tested the classical assumptions, namely normality, multicollinearity, heteroscedasticity, and autocorrelation tests. 


\section{AFEBI Economic and Finance Review (AEFR)}

\section{Volume 6, No 2 (2021)}

The results of the normality test using the Kolmogorov-Smirnov have a value of 1.21 and Asymp.Sig. (2-tailed) 0.11 is more significant than 0.05 . Thus, the data is normally distributed. The results of the multicollinearity test show that there is no independent variable that has a tolerance value of less than $0.1(10 \%)$. Besides, the VIF value is less than 10 , so it can be concluded that there is no multicollinearity. This study conducted a heteroscedasticity test using the Glejser test and had a sig value greater than 0.05 . Thus, this study did not show the occurrence of heteroscedasticity. Finally, the autocorrelation test has a Durbin-Watson value of 1.928 and $\mathrm{a} d u$ value of 1.8145 . The findings position between $\mathrm{du}<\mathrm{dw}<4-\mathrm{du}$ range $(1.8145<1.928<2.1855)$. Therefore, there are no positive or negative autocorrelation symptoms. The next step is to examine the research hypotheses presented in Table 2.

Table 2. The Results of Multiple Linear Regression Analysis

\begin{tabular}{|c|c|c|c|c|c|}
\hline Variables & $\begin{array}{l}\text { Unstandardized } \\
\text { B }\end{array}$ & $\begin{array}{l}\text { Coefficients } \\
\text { Std. Errors }\end{array}$ & $\begin{array}{l}\text { Standardized } \\
\text { Coefficients } \\
\text { Beta }\end{array}$ & $\mathbf{t}$ & Sig \\
\hline (Constant) & .010 & .002 & & 4.533 & .000 \\
\hline $\begin{array}{l}\text { Bonus } \\
\text { compensation }\end{array}$ & .005 & .001 & .261 & 6.905 & .000 \\
\hline $\begin{array}{l}\text { Institutional } \\
\text { ownership }\end{array}$ & -.015 & .001 & -.736 & -19.537 & .000 \\
\hline $\begin{array}{l}\text { Independent } \\
\text { commissioner }\end{array}$ & .002 & .004 & .008 & .550 & .583 \\
\hline $\begin{array}{l}\text { Audit committee } \\
\text { financial expert }\end{array}$ & .002 & .002 & .013 & .951 & .343 \\
\hline $\begin{array}{l}\text { Political } \\
\text { connection }\end{array}$ & .001 & .001 & .009 & .643 & .521 \\
\hline $\mathrm{R}$ & .983 & & & & \\
\hline $\mathrm{R}^{2}$ & .967 & & & & \\
\hline Adjusted $\mathrm{R}^{2}$ & .966 & & & & \\
\hline F Hitung & 1034.688 & & & & \\
\hline Significance F & .000 & & & & \\
\hline \multicolumn{6}{|c|}{ Dependent variable: earning management } \\
\hline
\end{tabular}

a. Predictors: (constant), bonus compensation, Institutional ownership, independent commissioner, audit committee financial expert, political connection

b. Dependent variable: earning management

Source: processed data (2021)

Table 2 presents the Adjusted R Square value of 0.966. The value implies that the variation in earnings management activities is predisposed by bonus compensation, institutional ownership, independent commissioners, financial experts of audit committees, and political connections of $96.6 \%$. The remaining $3.4 \%$ is influenced by other factors not explained in this model. The results of multiple linear regression have a significance value of 0.000 which is smaller than 0.05 . Thus, all independent variables have a simultaneous effect on earnings management.

Table 2 also shows that only two independent variables affect earnings management, namely board compensation and institutional ownership. The bonus compensation variable has a positive coefficient direction and a significance of 0.000 . It is means bonus compensation improves earnings management. Therefore, the first hypothesis is supported. On the other hand, the institutional ownership variable has a negative coefficient direction and a significance of 0.000 . Thus, institutional ownership reduces earnings management. The second hypothesis is supported. The other three variables, namely independent commissioners, an audit committee with financial 
experts, and political connections, do not affect earnings management. The result has a significance value of $0.583,0.343$, and 0.521 . Thus, the statistical results don't support the third, fourth, and fifth hypotheses.

\section{Discussion}

Hypothesis 1 states that bonus compensation has a positive effect on earnings management. The results of hypothesis 1 present that bonus compensation has a positive effect on earnings management. If the company offers compensation (bonus scheme), the manager will motivate to manage net income to maximize bonus gains. These actions are performed through earnings management. Therefore, the higher the bonus offered, the higher the earnings management practices will commit, and vice versa. The results support previous studies (Elfira, 2014; Yustiningarti \& Asyik, 2017) that bonus compensation positively impacts earnings management. This study implied that bonus compensation motivates managers to work to maximize company profits. Beside, the compensation encourages managers to maximize performance to achieve the targeted profit value. Thus, bonus compensation increases the propensity of earning management.

The hypothesis 2 result support that institutional ownership has a negative effect on earnings management. This condition is due to institutional ownership has the competence to prevent managers' opportunistic behavior. Also, the large proportion of institutional ownership allows investors to supervise management companies, including financial reporting. The greater the number of institutional shareholdings, the lower the likelihood of earnings management practices. The results support previous research that institutional ownership and earnings management has a negative relationship (Nazir, 2014; Sumanto et al., 2014). These results imply that institutional ownership plays an essential role in reducing earnings management.

Contrary to hypothesis 1 and hypothesis 2, the results of the hypothesis 3 test indicate that the proportion of independent commissioners and earnings management does not have a significant relationship. These results suggest that independent commissioners can not decrease earnings management behavior in manufacturing companies. It is a condition due to the independent commissioners do not perform their supervisory function properly. As a result, they have difficulty in supervising and controlling earnings management. Similar to previous research (Ananda \& Andriani, 2019; Asitalia \& Trisnawati, 2017), it is concluded that independent commissioners did not affect earnings management. Contrary, this result does not support the previous result that an independent commissioner effectively reduces the possibility of fraud (Mardjono \& Chen, 2020; Nazir, 2014; Rahmawati et al., 2017). This finding implies that companies must make independent commissioners more effective in overseeing company policies, especially those that can create earnings management.

The results of hypothesis 4 also failed to prove the relationship between financial experts of audit committee members and earnings management. It is means the financial or accounting expertise can not reduce earnings management practices. Bapepam regulations provide requirements for audit committee members to have accounting expertise. However, this regulation is not practiced correctly. There is a possibility that the company applies this regulation only to fulfill the regulation. In this case, the accounting or financial experts do not have the interest to protect the investors from the threat of earnings management. These findings were similar to previous research (Lestari \& Murtanto, 2018; Putri \& Erinos, 2019) that the financial expertise of audit committees did not influence earnings management. Nevertheless, the result of this study is in contrast to previous studies that showed the audit committee's member's financial expertise reduces earnings management practices (Inaam \& Khamoussi, 2016; Mardjono \& Chen, 2020; Widasari \& Isgiyarta, 2017; Zalata et al., 2018).

Finally, the hypothesis 5 test results state that political connections do not affect earnings management. Political connections do not affect earnings management practices because 


\section{AFEBI Economic and Finance Review (AEFR)}

\section{Volume 6, No 2 (2021)}

politically connected companies tend to be more closely monitored by the public. This condition causes the company to be more at risk of being more careful in carrying out earnings management practices. These findings similar to previous research (Hendi \& Ningsih, 2019; Puspitasari \& Nugrahanti, 2016) that political connections did not affect earnings management. Thus, this study implies that the existence of a political connection cannot always direct management to commit earning management. These results do not support the assumption that a political affiliation will affect interests or agreement that benefits both parties.

\section{CONCLUSION}

This study aims to examine the effect of corporate governance and political connection on earnings management. The empirical findings show that the bonus compensation has a positive effect on earnings management. Meanwhile, institutional ownership and earning management have a negative relationship. However, the other three variables, namely the independent commissioners, the financial experts of the audit committee, and political connections, do not affect earnings management. Three results fail to support the hypothesis, and it becomes a limitation of this study. Thus, further research recommended using other corporate governance variables, such as board of directors size, audit committee meeting, or public ownership.

\section{Reference}

Ananda, A. F., \& Andriani, S. (2019). Pengaruh dewan komisaris independen dan komite audit terhadap manajemen laba pada perusahaan manufaktur yang terdaftar di Bursa Efek Indonesia tahun 2015-2017. JAMIN : Jurnal Aplikasi Manajemen Dan Inovasi Bisnis, 2(1), 88. https://doi.org/10.47201/jamin.v2i1.46

Antonius, R., \& Tampubolon, L. D. R. (2019). Analisis penghindaran pajak, beban pajak tangguhan, dan koneksi politik terhadap manajemen laba. Jurnal Akuntansi, Keuangan, Dan Manajemen, 1(1), 39-52. https://doi.org/10.35912/jakman.v1i1.5

Asitalia, F., \& Trisnawati, I. (2017). Pengaruh good corporate governance dan leverage terhadap manajemen laba. Jurnal Bisnis Dan Akuntansi, 19(1a), 109-119. https://doi.org/10.34208/jba.v19i1a-2.305

Azizi, A., Mahsuni, A. W., \& Junaidi. (2018). Pengungkapan sosial, diversifikasi perusahaan dan kompensasi bonus terhadap manajemen laba pada perusahaan manufaktur yang terdaftar di Bursa Efek Indonesia tahun 2015-2017. E-JRA, 07(01), 32-45. https://doi.org/10.1186/1476-4598-10-45

Braam, G., Nandy, M., Weitzel, U., \& Lodh, S. (2015). Accrual-based and real earnings management and political connections. The International Journal of Accounting, 50(2), 111-141. https://doi.org/10.1016/j.intacc.2013.10.009

Cnbcindonesia.com. (2019). Laporan Laba Janggal, OJK Minta BEI Periksa Manajemen Garuda. https://www.cnbcindonesia.com/market/20190502201304-17-70218/laporanlaba-janggal-ojk-minta-bei-periksa-manajemen-garuda

Dalia, N. W. P., Rustiarini, N. W., \& Dewi, N. P. S. (2021). Pengaruh perjanjian utang, koneksi politik, penghindaran pajak, pergantian CEO, dan kompensasi bonus terhadap manajemen laba. KARMA (Karya Riset Mahasiswa Akuntansi), 1(2), 668-679. http://ejournal.unmas.ac.id/index.php/karma/article/view/1973

Dwiharyadi, A. (2017). Pengaruh keahlian akuntansi dan keuangan komite audit dan dewan komisaris terhadap manajemen laba. Jurnal Akuntansi Dan Keuangan Indonesia, 14(1), 75-93. https://doi.org/10.21002/jaki.2017.05

Elfira, A. (2014). Pengaruh kompensasi bonus dan leverage terhadap manajemen laba (Studi empiris pada perusahaan manufaktur yang terdaftar di Bursa Efek Indonesia tahun 20092012). Jurnal Akuntansi, 2(2), 1-15.

Ghozali, I. (2016). Aplikasi Analisis Multivariete IBM SPSS 23. In Semarang. Universitas 
Diponegoro.

Haque, F. (2017). The effects of board characteristics and sustainable compensation policy on carbon performance of UK firms. The British Accounting Review, 49(3), 347-364. https://doi.org/10.1016/j.bar.2017.01.001

Haryati, P. D. G., Rustiarini, N. W., \& Dewi, N. P. S. (2021). Pengaruh corporate governance dan koneksi politik terhadap nilai perusahaan. Kumpulan Hasil Riset Mahasiswa $\begin{array}{llll}\text { Akuntansi } & \text { (KHARISMA), 3(1), 279-289. }\end{array}$ journal.unmas.ac.id/index.php/kharisma/article/view/1705

Healy, P. M. (1985). The effect of bonus schemes on accounting decisions. Journal of Accounting and Economics, 7(1-3), 85-107. https://doi.org/10.1016/01654101(85)90029-1

Hendi, H., \& Ningsih, I. P. W. (2019). Pengaruh koneksi politik dan transaksi pihak berelasi terhadap manajemen laba pada perusahaan yang terdaftar di Bursa Efek Indonesia. Global Financial Accounting Journal, 3(2), 38-50. https://journal.uib.ac.id/index.php/gfa/article/view/659

Inaam, Z., \& Khamoussi, H. (2016). Audit committee effectiveness, audit quality, and earnings management: A meta-analysis. International Journal of Law and Management, 58(2), 179-196. https://doi.org/10.1108/IJLMA-01-2015-0006

Jensen, M. C., \& Meckling, W. H. (1976). Theory of the firm: Managerial behavior, agency costs, and ownership structure. Journal of Financial Economics, 3(4), 305-360. https://doi.org/10.1016/0304-405X(76)90026-X

Juhmani, O. (2017). Audit committee characteristics and earnings management: The case of Bahrain. International Journal of Accounting and Financial Reporting, 7(1), 11-31. https://www.researchgate.net/profile/Omar_Juhmani/publication/

Khosheghbal, M., Amiri, A., \& Ali, H. (2017). Role of audit committees and board of directors in reducing earning management of companies listed in Tehran Stock Exchange. International Journal of Economics and Financial Issues, 7(6), 147.

Kovermann, J., \& Velte, P. (2019). The impact of corporate governance on corporate tax avoidance - A literature review. Journal of International Accounting, Auditing, and Taxation, 36(9), 100270. https://doi.org/10.1016/j.intaccaudtax.2019.100270

Lestari, E., \& Murtanto, M. (2018). Pengaruh efektivitas dewan komisaris dan komite audit, struktur kepemilikan, dan kualitas audit terhadap manajemen laba. Media Riset Akuntansi, Auditing \& Informasi, 17(2), 97. https://doi.org/10.25105/mraai.v17i2.2063

Mardjono, E. S., \& Chen, Y.-S. (2020). Earning management and the effect characteristics of audit committee, independent commissioners: Evidence from Indonesia. International Journal of Business and Society, 21(2), 569-587.

Marsha, F., \& Ghozali, I. (2017). Pengaruh ukuran komite audit, audit eksternal, jumlah rapat komite audit, jumlah rapat dewan komisaris, dan kepemilikan institusional terhadap manajemen laba (Studi empiris perusahaan manufaktur yang terdaftar di BEI tahun 20122014). Diponegoro Journal Of Economics, 6(2), 91-102. https://ejournal3.undip.ac.id/index.php/accounting/article/view/18245

Moradi, M., Salehi, M., \& Zamanirad, M. (2015). Analysis of incentive effects of managers' bonuses on real activities manipulation relevant to future operating performance. Management Decision, 53(2), 432-450. https://doi.org/10.1108/MD-04-2014-0172

Murni, Y., Sudarmaji, E., \& Sugihyanti, E. (2016). The role of institutional ownerships, board of independent commissioner, and leverage: Corporate tax avoidance in Indonesia. IOSR Journal of Business and Management, 18(11), 79-85.

Nazir, H. (2014). Pengaruh kepemilikan institusional, komposisi dewan komisaris independen, reputasi kantor akuntan publik, dan kompensasi bonus terhadap manajemen laba (Studi empiris pada perusahaan finance yang terdaftar di BEI tahun 2008-2011). Jurnal 


\section{AFEBI Economic and Finance Review (AEFR)}

\section{Volume 6, No 2 (2021)}

Akuntansi, 2(1), 1-13. http://ejournal.unp.ac.id/students/index.php/akt/article/view/863

Pranoto, B. A., \& Widagdo, A. K. (2015). Pengaruh koneksi politik dan corporate governance terhadap tax agressiveness. Seminar Nasional Dan The 3rd Call for Syariah Paper.

Prasetya, P., \& Gayatri, G. (2016). Pengaruh ukuran perusahaan terhadap manajemen laba dengan pengungkapan corporate social responsibility sebagai variabel intervening. $E$ Jurnal Akuntansi, 14(1), 511-538. https://simdos.unud.ac.id/

Puspitasari, A., \& Nugrahanti, Y. W. (2016). Pengaruh hubungan politik, ukuran KAP, dan audit tenure terhadap manajemen laba riil. Journal Akuntansi Dan Keuangan, 18(1), 2743. https://doi.org/10.9744/jak.18.1.27-43

Putri, N. G., \& Erinos, N. (2019). Pengaruh keahlian akuntansi komite audit dan dewan komisaris wanita terhadap manajemen laba (Studi empiris perusahaan manufaktur yang terdaftar di Bursa Efek Indonesia tahun 2015-2017). Jurnal Eksplorasi Akuntansi, 1(3), 1051-1067. https://doi.org/10.24036/jea.v1i3.127

Rahmawati, M., Dewi, V. S., \& Hikmah, S. N. (2017). Pengaruh kualitas auditor dan corporate governance terhadap manajemen laba (Studi empiris pada perusahaan manufaktur yang terdaftar di Bursa Efek Indonesia periode 2011-2016). Proceeding 6th University Research Colloquium 2017: Seri Humaniora, Sosial, Dan Agama, 459-474. http://journal.ummgl.ac.id/index.php/urecol/article/view/1568

Rustiarini, N. W., \& Sudiartana, I. M. (2021). Board political connection and tax avoidance: Ownership structure as a moderating variable. Jurnal Dinamika Akuntansi Dan Bisnis, 8(2), 128-148. https://doi.org/10.24815/jdab.v8i2.20760

Scott, W. R. (2009). Financial Accounting Theory. Prentice Hall.

Sugiyarti, S. M. P. L. (2017). Pengaruh Intensitas Aset Tetap, Pertumbuhan Penjualan Dan Koneksi Politik Terhadap Tax Avoidance (Studi Kasus Pada Perusahaan Manufaktur Yang Terdaftar Di Bursa Efek Indonesia Tahun 2012-2016). Jurnal Riset Akuntansi Dan Keuangan, 5(3), 1625-1642.

Sulistyanto, S. (2008). Manajemen Laba (Teori \& Model Empiris). Grasindo.

Sumanto, B., Asrori, A., \& Kiswanto, K. (2014). Pengaruh kepemilikan institusional dan ukuran dewan komisaris terhadap manajemen laba. Accounting Analysis Journal, 3(1), 44-52. https://journal.unnes.ac.id/sju/index.php/aaj/article/view/3901

Widasari, T., \& Isgiyarta, J. (2017). Pengaruh keahlian komite audit dan jumlah rapat komite audit terhadap manajemen laba dengan audit eksternal sebagai variabel moderasi. $\begin{array}{llll}\text { Diponegoro Journal Of Economics, } & \text { 6(4), }\end{array}$ https://ejournal3.undip.ac.id/index.php/accounting/article/view/18205

Yustiningarti, N. D., \& Asyik, N. F. (2017). Pengaruh asimetri informasi, mekanisme corporate governance dan kompensasi bonus terhadap manajemen laba. Jurnal Ilmu Dan Riset Akuntansi, 6(1), 31-40. http://jurnalmahasiswa.stiesia.ac.id/index.php/jira/article/view/1571

Zalata, A. M., Tauringana, V., \& Tingbani, I. (2018). Audit committee financial expertise, gender, and earnings management: Does gender of the financial expert matter? International Review of Financial Analysis, 55(1), 170-183. https://doi.org/10.1016/j.irfa.2017.11.002 